\title{
Maraila: Exploring the Meaning of Kapata in a CustomaryPatita Banquet of Tuni Clan in Oma
}

\author{
Febby Nancy Patty ${ }^{1}$, Weldemina Yudit Tiwery ${ }^{2}$, Agusthina Ch. Kakiay ${ }^{3}$, \\ Selvone Pattiserlihun ${ }^{4}$ \\ Ambon State Institute for Christian Studies, Jl. DologHalong Atas, \\ Indonesian-Mollucas \\ fenansia@gmail.com¹, yuditheo@gmail.com², \\ agusthinkakiay@gmail.com ${ }^{3}$,selvone.pattiserlihun@gmail.com ${ }^{4}$
}

\begin{abstract}
Maraila is a traditional song which in Maluku local term is called kapata. This song is usually used to accompany the dance in the traditional patita banquets by Soa (Clan) Tuni in Oma Island, Haruku Island. As a traditional song, Maraila has many symbols and meanings that need to be studied to contribute to theological values in the context of Maluku society. This study aims to explore the wealth of meaning contained in the tradition of Maraila by using a cultural interpretation approach. Interpretation of symbols and meanings in the tradition is important because; (1) songs in the traditions of Christian indigenous peoples are more dominated by European songs (centered on Europe), thus the space for traditional songs that are rich in moral ethical values tends to be closed. (2) Customary songs are considered lack of theological values than the songs of European heritage. By using a cultural interpretation approach to the tradition of the traditional Maraila song, there is a room to hear other voices from the experiences of the people in Maluku, especially the Oma village which has been marginalized (periphery). Maraila is a way for people to build, devote and pass on the quality of life values to each generation. The results of this study indicate that Marailahas moral ethical values as well as being a theological model in contextual relations with God, community and the nature.
\end{abstract}

Keywords: Maraila, kapata, custom, symbols, contextual theology

\section{Introduction}

Despite the shift, but actually the appreciation and even obedience of the people to their customs is not completely lost. This reality is indicated through the discovery of a variety of customary wealth that is still stored and practiced in the Maluku people's way of life. A custom is valued forit is an ideal form of culture which usually functions as a code of conduct that regulates, controls and directs people's attitudes and actions in society. In every culture, there are myth, ethos and rite which have become recognized traditions and are tangible ancestral heritage in clothing, houses, musical instruments, songs, dances and others. The local wealth is also found in the living practices of the Oma people known as kapata. Kapatais an ancestral tradition and it is still maintained to the present time. Kapatais a form of oral tradition which contains moral messages that are usually spoken or sung by Maluku people. Kapatais usually sung in the native language of the local community at traditional ceremonies. For example, during the inauguration ceremony of the king and the head of soa(clan), 
welcoming guests, PanasPela and Gandong, treasure-carrying ceremony, and others [1], [2], $[3]$.

Although kapatais rarely used, the people of Oma are still using it. Kapatathat is examined in this research is Marailathat is sung at patitacustomary ofsoaTuni.Soa is a collection of several family in a clan[4], [5], [6]. Maraila or kapatais only sung in the administration of a patitacustomary. Patita customary, is a banquet traditionthat is conducted where the uncles will invite his sisters (and their children) to be hosted on the benquat table. Kapataor Maraila contains the values of ethics and morals such as: the value of peace, values of respect, brotherhood, the value of love which subsequently became the benchmark for the community to build relationships both with God and others (including ancestral and nature of the universe).

This research was conducted to explore the Maraila tradition through a cultural interpretation approach to discover how the Oma community interpreted the symbols contained in the song. Through cultural interpretation, it is hoped that the values in Maraila as well as the symbols can be revealed.

\section{Theoretical Framework}

\subsection{Previous Relevant Studies}

The study of local traditions and historical socio-historical moments of the Maluku people with all their dance and singing activities is not the first for researchers to do. Much earlier there had been research on traditions in which kapata had been carried out by FalentinoLatupapua, P.S.Letlora; E.MSolissa and Y. Kesauliya, LH Lelapary and L. Pattipeiluhu. Latupapua in the research put kapataas oral literature in the level of Maluku culture. Kapatais included in the type of songs of the people of Maluku that contain certain stories and messages. The stories and messages in the kapataare intended to communicate the teachings and advice of the ancestors to the next generation. Its use in each of the rituals of indigenous villages, for example in the event of the inauguration of the king, the panaspela and gandong, cuci negeri.

Furthermore, Letlora examine the text ofkapatain Saparua, Central Maluku. Based on his findings, he explained thatkapata text contained symbols both in nouns and adjectives. Generally, it has denotative and connotative meaning [7]. While EM Solissa and Y. Kesauliyaconducted their reseach about kapatafocuses on the study of form and function to the tradition of panas pela in Sirisori, Tamilouw and Hutumury. The results shows that the kapataused in pela gandongtradition is functioned as function as accompaniment song. In terms of meaning, Kapatahas historical significance (historical), allegorical, anthropological and anagogic meaning. Meanwhile in terms of function, it isa speaker of history, a tool to advise, accompaniment of customary rituals and the social control [8].

On the other hand, L.H.Lelapary in his writings on the characteristics of the oral kapatatradition in Maluku through ethnographic studies, argues that kapatais a form of language that is specifically used by the community in traditional ceremonies, with certain rhythms, arranged in lines and delivered in the form of monologues and dialogue. This form is only used at regular cultural ceremonies and is used by certain people, such as the head of the villagewho takes control the over the customary. Kapatais a form of oral tradition that belongs to an oral folklore that has long lived in a community's tradition, whether people have known writing or not. The study found that the function of verbal tradition is referred to function theories which includes folklore functionalism theory, the theory of socio folklore, folklore 
psychofunction theory, the theory of functions of ethnocentrism and function of fetishism. The values in the tradition is held in private and internalized in the behavior. Value is also a cognitive unit that is used to weigh the scales of good or bad, just not right, correct wrong and also refers to what is done. While religious values are values that have the strongest basis for truth. This value comes from the highest truth, God [9].

According to F. Darman, kapatais one form of oral literature is known by most people of Maluku, and sung in a the local language during the ceremony or traditional rituals. Itisalways part of the ceremony and adds to the sacredness of the ceremony. It also holds many historical values and life values inherited from the ancestors. In his research, he examines the historical reality and the function and meaning in oral literature kapata war Kapahahalocated in the village of Morella, Leihitu District, Central Maluku. The study used hermeneutic approach and content analysis to see the structure and meaning in kapata. The analysis showed, kapata war Kapahahahas historical significance that reflect history in the past so that it can be considered as a source of historical speakers and accompaniment of customary rituals [10].

\subsection{Rituals and Symbols}

Understanding religious practices (rites) is inseparable from the cultural system of its people. Geertz said that religious rites are a means of establishing one's identity and status, and the grouping of rituals reflects political opposition, or myths provide the basis for social institutions and the rationalization of special social rights. According to Geertz, culture consists of patterns or networks of meaning that are passed on historically which are manifested through symbols, a system of inherited concepts that are revealed in symbolic forms through which humans communicate, preserve and develop their knowledge and attitudes about life. Therefore, in order to understand its meaning, a profound interpretation of culture/cultural symbols is needed, which it refers to as a deep description or thick description [11], [12]. Commentary to culture a n says is an attempt to understand the social reality and explore what the native's point of view (viewpoint of cultural actors themselves) are descriptive and distinctive. Through this approach, researchers can interpret why, background, function and purpose of existing cultural elements. Geertz further argues that culture is something that is associated with symbols that seem real (real) and unique and enforced by the community. Which symbols are considered sacred symbols function to synthesize a nation's ethos, namely: the tone, characteristics and quality of their lives, their morals and aesthetic style and moods, and their worldview that is the picture they have of how to act, ideas the most comprehensive of the cosmic order [13].

So that religion for Geertz is: A system of symbols that applies to establish a strong mood and motivations, which contain concepts about the order of the universe. These concepts must be understood as radiant what is experienced and felt by men seen in mood and motivation strong. Furthermore, cultural patterns determine the symbols that have links and relationships with one another both in the organic, social and psychological systems which he calls a "model". The model has meaning. And that meaning must be understood in a more complex social system and network. So that the culture and symbols are doubly divided into 2 namely "models of" (models of ) of reality and "models for" (models for ) reality that is idealized or expected. Cultural symbols must be understood in human experience and function to shape their world [13]. 


\subsection{Kapata}

Kapataare Maluku folk songs that are sung in the language of indigenous people who tell an event or are informational [14]. In the Maluku cultural environment, kapatahas been widely known as a speech tradition that can be said as oral literature that is brought collectively by indigenous groups in various traditional rituals and daily life. The term kapatain this case can be understood in a concept that is almost similar to the concept of folk singing as proposed by Danandjaya, namely lyrical folk singing, that is folk song that tells about something. Folk song (folksong) is a genre or form of folklore consisting of words and songs that circulate orally among certain collective members, traditional forms, and many variants. Kapatais an oral folk song in Maluku (Central) that uses local language.

Kapatacan be said to have the function and potential to educate the public about the positive values that exist within the community itself, as an effort to raise collective awareness about the importance of revitalizing tradition and culture. Besides the educational function, where the substance of the kapatais sociologically functioning to maintain the norm of community alliance with religious-magical properties. Through speeches that contain certain values, kapata emphasizes the collective identity associated with social norms and order in certain groups of people with essential values that must be maintained. So kapata is always presented and witnessed massively by involving various segments of the community [2].

According to Latuapua, there are 5 functions of kapata. Of the above functions, the most prominent is the supporting function of traditional rituals, where most of the kapatatexts that are scattered in the customary lands in Central Maluku are sung at the time of traditional rituals (inauguration of the king, traditional marriage, guest reception, life cycle rituals and so on). In addition to the above functions, kapataalso functions as a preserver of history and a vehicle for collective historical speech. The function of the kapataas a vehicle for history speakers is a vital function in providing references to the history of society. Kapataalso functions as a spirit generator, especially when doing individual or collective work. Another function is the function of harmonization and social control. The functions include the kapataadvice from parents to their children, or of the king and the people. Besides thatkapataalso functions to maintain the sanctity of customary institutions and enforce customary laws that have been agreed upon in certain groups as well as to maintain traditional relations that have been flying for a long time [2], [8].

\section{Methodology}

This research uses a qualitative approach. This approach is considered appropriate because it emphasizes more attention to the process than the results and involves an intensive relationship between researchers and informants [15], [16].This is important because the researcher aims to express the subject's understanding and research informants about the kapata or traditional songs and the meaning or value contained therein. Data collection techniques are carried out through secondary data obtained through literature, print media and scientific articles. The form of primary data collection is done through observation and indepth interviews with informants who are the people of Oma country. The data that has been collected, then analyzed using an interactive model that includes the stages of data reduction, data presentation and drawing conclusions. This research was conducted inHaruku Island, Oma village in 2019 . 


\section{Result and Discussion}

\subsection{Poetry, Meaning and Importance of Maraila}

Marailaare songs of joy or "barsuka" or literally means singing and dancing, between the uncles with children who voiced happiness (PW; FW; OH; EH) ; When Maraila, we must have fun in excitement, singing, dancing, we have fun with the children, children are also have fun with us, so both parties are equally have fun, we are both singing and dancing (DK ; FK) . In other words, marailais an expression of joy that is performed through dance and singing in a traditional way of singing. As a traditional song, Marailaconveys a special (sacred) message to its members. People of Oma also assume that marailacan only delivered in a customary patita banquet, and the use of indigenous languages. There are 4 Maraila songs that are sung. For more details, the song lyrics can be seen below:

\section{a) The First Song}

SopaMea o ... UpuTunia Rima e... Wa a Ina Rima ... e (2x)

Ale Kita Lemba Lisa e ... e ...

Dimalige o ... o ... Otabeahoromate o ... o ... (2x)

Meaning:

Let's praise / respect the ancestors or progenitors,

Mr. Lima-Lima, Mrs. Lima-Lima

We walk together...

Heading to gathering spot ... werespects the clans ...

\section{b) The Second Song}

SopaMeaUpu Latu Ey o RumahRualatu o...

Wa ... a ... Upu Toru o Kemanuayasiwa o ... o ... (2x)

TuniaSrimaSiamiHoka Yama City e ... e ...e ...

KitaLembalisaNusu Lei o ... o ... o ... (2x)

Meaning:

Let's praise / respectful to the ancestor / ancestors of clans Latu

For three ancestor / ancestors of clans UpuRualutu's

Coming from the tuni clan

Respect /praise

The progenitors / 5 ancestors ofTunia

\section{c) The Third Song}

SopaMea o ... UpuTunia Rima e ... Wa a Ina Rima ... e ... (2x)

Ale Kita e ..., KitaLembalisa ... he ... ee ...

Lembalisa Nusu Tatipea o ... o ...

Solo:

Onemu sadiki, tingkahlakumu sadiki,

EsoklusaMomo mati o ... Sapa One Analagi

(After the solo, everyone sings the song)

Meaning: 
Praise / respectful to the progenitor / ancestors of Teun

Mr. Lima-Lima, and Mrs. Lima-Lima

We walk ... We walk to Tenun

Enter clans Tatipea

WeMaraila with children,

If the day after tomorrow the uncles have died, what will you want to be sing together with children.

\section{d) The Fourth Song:}

TabeaHoromateUpu Rima ... Rima e ... Wa a Ina Rima e ... (2x)

Momo Ronda, Meme Momo Ronda Keep e ... e ...

Ronda jaga lariNusuTatipea o ... (2x)

Ale Nusu e... Nusu to Gusepa e ... e...

Hinia Rima Nusu To Gusepa e ... e ...

Ale Nusu e ... Nusu to Gusepa e ... e ... Nisaaru o ...

Embossed Pele Nisanelat o ... (2x)

Solo:

$O$... Matanatir e ... TuniaRambangMuluMatanatir ... e ...e ...

O KanahaitKayupu o...

Ale HiniaRimakanaHait ... o ... o ...

(2x, after the solo everyone sings)

Meaning:

Greetings, respect / praise the ancestor 5 progenitor... Mr. Lima-lima and Mrs. Lima-Lima (wife)

Uncles walk ... Hopefully

the ancestors walk to guarded the uncles and the children

Walk around to Tatipea $(2 \mathrm{x})$

Walk to ... towards GusepaArumbai

Lift and carrier up the children to the gusepa

Walk to gusepa..in Saaru

Prevent from Saaru ... from obstacles

Hi spokesman

Namely RambangMuluTunia (Head of Soa)

Be careful and always remember in doing your job

As the Chairperson of the Mr. Lima-lima

Maraila is very important for the people of Oma, because it is an important element of the customary patita event. Without Maraila, the event could not be done. Marailais also called the customarykapata. Through Maraila, the people of Oma can remember and know historical events and carry them on from generation to generation. So that Marailanot only contains history but also has meaning. This is the importance of Marailafor the people of Oma. 


\subsection{Maraila Function}

There are five function of Maraila, namely: as a supporter of the ritual. The Oma community in particular Tuni clan considers that Maraila is not only a supporter of rituals but is an important element of the rules for implementing customary paptita; The keeper of history, Marailatells the journey of the ancestors in the past. So through Maraila, they know what they want to do. Maraila conveyed the messages of the ancestors so that they could live in peace with one another; The harmony and social control, Marailadelivers message of parents which is function as social control in the midst of a crisis situation; the function of language and cultural enrichment, lies in the Maraila tradition which is verbally transmitted to the community. Maraila is also sung repeatedly and passed down from generation to generation; Functional recreation and encouragement, where Maraila is a song of gratitude, joy, and excitement performed between the uncles and children.

\subsection{The Meaning Contained in the Maraila Poetry}

From the research, marailacontain profound meaning. Some values include:

\section{a) Respect}

Attitude and value of respect is very dominant in Maraila. Each song begins with a message as well as an invitation to respect (sopa) to the ancestors and their clans repeatedly (4 times use the word SopaMea $O$ ). The word "sombah" or "respect" refers to an attitude of submission to the ancestors along with Mr. Lima-Lima (Mrs. Five-Five) as the leader or parent including the ancestors of the clans, because that's where life radiates.

Respect includes: respect/praise to God because God has created and nurtured all life and its contents are their lives. God has also allowed the Maraila and customary patita events to take place, so that they can live well and safely (tabea). In addition, respect/praise to the ancestors. They were the first to have put the tradition to live communion to the present time. Furthermore, respect/praise to the leader and ancestor. Leaders and parents as leaders, protectors, and at the same time as father. Through their teaching, they have to set an example through Marailaand customarypatita. Including respect for the limits or rights of others (fellow).

\section{b) Fellowship and Togetherness}

There is also the fellowship and togetherness. In Maraila, there is no place for individuals. Each individual merged or united in the life of community or togetherness. Baileusoa (traditional house of the clan) is a symbol of the origin of life from which the life of fellowship gets a bond or promise in an oath together as brothers.

Several terms that emphasize aspects of the namely: " katong" (we), "marikatong" (let us), "katongsamua" (we all). These terms refer to a community, namely fellowship as brothers. The words: "katongbakumpul" (we gather), "katongdatang" (we came), "katongmenuju" (we headed), "katonghormati" (we respect also refers to the dimension of fellowship or unity that exists between them. That is, through Maraila, everyone is invited and directed to abandon self-interest or selfish attitudes (selfishness), and look at common goals and intentions. This appears dominant from the preparatory stage to its implementation. 
In addition, the poetry: "katongbajalang" (we walk), "katongbajalangbersama-sama" (we walk together). According to the people of Oma, life is compared to a journey of life that must be passed collectively rather than individuals (together). In their journey they face challenges and as siblings, they also have to face them together. This is where the values of fellowship and togetherness are emphasized and become an imperative in shared life. These values are not only sung but must be realized in everyday life.

The fellowship and togetherness do not only include one element of life namely human beings but all elements namely: the transcendent element (God), the Patriarchs and the universe are involved together.

\section{c) Love and Compassion}

The attitude of love and compassion appears in the attitude of the leaders (traditional elders). The uncles really loved and felt the suffering experienced by their sisters and children. These attitudes and feelings manifest when they invite and feed their children at the customarypatita. When Maraila, the uncles, along with Mr. and Mrs. Lima-Lima express an expression of deep love that invites children to eat and sit at the customarypatita table. At the dining table a variety of foods are provided by the uncles. They do not only provide but also invite, picks up, carries, and goes hand in hand together. It was done with joy and even the they also protected the children from the obstacles. That is proof of their love and sacrifice that protects the lives of their children.

\section{d) Value of Barsuka (Joy)}

Maraila is an expression of pleasure, joy and excitement. These expressions appear when Marailaceremony. Theattitudeinvolves feelings of joy, happy, gratitude, excitement, that are shown in the expression, face, words, inheritance and all movements of the limbs (dancing). The attitude or feeling isshown by both people who reside in Oma and those who come from overseas so that the attitude and feeling arerelated to the "events" that children should celebrate. Therefore, the event must be conducted with a heart joy(happy, delight, rejoicing).

When Marailais conducting, all the people sang, joy and dance accompanied by the sound of drums and gongs. Therefore, the people in a sad and burdened atmosphere were happy again. All sufferings seemed to move away and be replaced with a sense of joy. Attitude and joy values are very dominant. This is evident in the expressions of everyone who involved in it.

\section{e) Values of Struggle}

The value of struggle is also very dominant. History tells the story of the practice of violence and injustice, and therefore the power of crime must be opposed and resisted. What the uncle does is an example and spirit to fight together to do good things.

\section{f) Responsible}

Responsibility appears dominant in Maraila (songs 3 and 4). The uncles are responsible for protecting and carrying the lives of their children. In addition, this form of responsibility is carried out by picking up, carrying and walking together. Besides thatthe uncles also feed and servethe children at the banquet table. In the midst of challenges, they carry children through 
various dangers. It refers to the attitude of their responsibility towards the lives of their children including in the midst of crisis. On all text of Maraila, they are also stressing also about the responsibility of the head fromthe clan. The head of clan is the leader and parent who leads and nurtures for all members of clans Tuna. In carrying out their duties and responsibilities, they must be responsible for protecting and defending the lives of children properly and fairly.

\subsection{Theology of the Maraila Tradition}

Marailais a salvation event that God did through the ancestors in the past. The experience is worth to be remembered and celebrated together. The celebration is manifested in the expressions of joyand dancingwhich are expressed in the form of "hymns", a sense of excitement "and" joy ", "cheers "and dances (body movements rotating and jumping). The kindness and salvation from God is revealed in the term tabeawhich means "safe", "protected", and "good". Through Maraila, the Oma people celebrate the salvation and life that God has done. Because of this, Maraila is considered a meaningful and sacred event of past, present and future generations. InMaraila, there is recognition that all the elements are there (God, ancestors, human and natural) participated converge and celebrate life together.

The Bible contains many texts that narrate the "event of deliverance" experienced by people because of God's salvation for his people. The event of salvation and deliverance should be celebrated with expressions of gratitude and joy that manifest in the singing and praise of the people that also involve members of the body (dancing). Some texts include Exodus 15:18; II Samuel 6:14, 15. In Exodus 15 narrated the event of salvation carried out by God, which was greeted with praises (songs) and dances from the Israelites and Moses (Exodus 15:18). The text tells the life experience of the people of Israel who were freed and saved by God from suffering. As stated also in in II Samuel 6. In the story tells about how King David together with the people of Israel raised praise to God. David sang and danced with all his might, he was dressed in ephod and linen. He also jumped and danced before the Lord (II Samuel 6: 14-15). What David did was an expression of gratitude and joy for the actions and events of God's love that have guided and protected them from danger. Expressions of gratitude and joy appear in the words and all members of his body: singing, dancing, jumping up and down accompanied by cheers and trumpets.

What is done by the people of Oma and the people of Israel is a form of celebration of faith or celebration of faith. Marailais a celebration of faith about salvation and deliverance that God has done for them through the uncles' actions to their children. The historical experiences of the two communities are unique and specific experiences that have meaning in their lives.

Maraila also contains moral character who teaches everyone to know and act properly. On the one hand, aspects of moral ethics emphasize the virtues that are owned by the community while character refers more to the dimensions of character, namely the cultivation of habits so that people can understand, feel and do good. Maraila contains the values of collectivity that teach humans to think and act properly and correctly. The humans in their limitations often commit crimes, but on the same side, there is their awareness to build a good life in accordance with the values of goodness ordered by God and the ancestors. The Marailavalues are a guideline for the people of Oma to be able to live a higher quality of life.

Marailacontains ethical and moral values and characters that refer to the life narratives of the people of Oma. Which moral and character ethical values are explained by Stanley Hauerwas in John ChrRuhulessin[17], [18]. Maraila contains a vision of life and salvation for 
the universe. Besides, the value of virtue or truth serves as a guide or compass as well as a guide for the life of both individuals and collectivity. So that everyone involved feels responsible for manifesting these values in everyday life. These values include love, compassion, protection, respect, fellowship, togetherness, brotherhood, peace and responsibility. These values are not only believed, but also lived and carried out from generation to generation. The character value of Marailarefers to the "identity" of the perpetrators. The character arises from the habituation process that is formed through knowledge and behavior both in Maraila and in everyday life. These actions are carried out repeatedly. This character is what distinguishes them from the others. This moral character is prominent in the Marailatradition and even appears prominently in biblical texts. The Apostle Paul in his letter advised Christians to do: love, truth, justice, peace, togetherness and others. These values become markers or identities which further distinguish Christianity from others.

Marailaas a media that communicates the message of living in peace as a brother and sister that: they have to love each other and create a peach among them. Baileusoa(traditional house of the clan) or Tatipea is a symbol that refers to the brotherhood that is built between them as younger siblings and older siblings and vice versa. It was there that the life of the fellowship radiated and continued to be maintained, one of which was through the tradition of Maraila. Respect for baileusoa or clan is respect for the ties of fellowship or brotherhood that has been built by the ancestors. So to uphold or respect the ties of fellowship is identical to respecting or upholding the values of life. Everyone is loved and embraced, loved, cared for and fed by the uncles. Everyone sat together at one table. Both those who lived and those who had migrated, men and women, healthy and sick/disabled people, rich and poor, were all loved and participated in the event. It does not only refer to aspects of togetherness but also the value of equality and justice. Maraila delivered a message of peace, where people must build peaceful relations and harmony with one another.

InMaraila, peaceful relations emphasis include relational aspects with human beings also with God and the ancestors even the natural surroundings. A rift in a relationship with one of the elements will cause disharmony in the cosmic order and cause disaster. Therefore in Maraila, a message of peace among all communities was proclaimed. Marailabecame a model for people to live as brothers.

\section{Conclusion}

The kapataor traditional songs of Marailaare the local wisdom of the Oma community, specifically the clans Tuna, containing profound theological meaning or values. The values arise from people's life experiences with various problems, namely socio, historical and cultural backgrounds. These factors contribute to society in understanding their world, including others, God, ancestors and the natural environment. Marailaisnot only important to the people of Oma, but through it they also shape their history. Marailacontains symbols that become models for people to build peaceful live. It also contains the value of gratitude about life (salvation), moral character, and conveys the message of "living as brothers". 


\section{References}

[1] Tutuarima, F. (2010). Kapata sebagai Wahana Penutur Sejarah dan Harmonisasi Sosial Masyarakat Maluku.

[2] Latupapua, F. E. et al. (2012). Kapata Sastra Lisan Di Maluku Tengah.

[3] Piter, W. S. (2018). Kapata in The Communities of The Amahai State Amahai Regency of Maluku Central District.

[4] Ajawaila, J. (2014). Orang Ambon dan Perubahan Kebudayaan. Antropologi Indonesia, 16-25.

[5] Salhuteru, M. (2015). Rumah Adat Baileo di Kecamatan Saparua Kabupaten Maluku Tengah. Jurnal Kapata Arkeologi,11 (1), 11-20.

[6] Handoko, W. (2017). Dolmen Orang Maluku: Eksistensi Religi, Adat dan Integrasi Sosial (Tinjauan Etnoarkeologi). Jurnal Penelitian Arkeologi Papua Dan Papua Barat,1 (2), 127-132.

[7] Letlora, P. (2018). Symbol and Meaning of Kapata Oral Tradition Texts in Central Maluku. ELS Journal on Interdisciplinary Studies in Humanities, 1 (2), 153-161.

[8] Solissa, E. M. (2015). Bentuk dan Fungsi Kapata Adat Panas Gandong di Negeri Tamilouw, Hutumuri dan Sirisori. Jurnal Tahuri, 12 No 1.

[9] Lelapary, L. H. (2011). Karakteristik Tradisi Lisan Kapata Di Maluku, Kajian Etnografi.(Tesis). Disertasi dan Tesis Program Pascasarjana UM.

[10] Darman, F. (2017). Realitas Sejarah dalam Sastra Lisan Kapata Perang Kapahaha Desa Morella, Pulau Ambon. Jurnal Kapata Arkeologi, 13 (2), 131-140.

[11] Geertz, C. (2003). Thick description: Toward an interpretive theory of culture. Culture: Critical concepts in sociology.

[12] Geertz, C. (2008). Thick description: Toward an interpretive theory of culture. In The cultural geography reader.

[13] Geertz, C. (1992). Kebudayaan dan Agama. Yogyakarta: Kanisius.

[14] Sahusilawane, F. (2005). Cerita-Cerita Tua Berlatar Belakang Sejarah dari Pulau Seram. Balai Kajian Sejarah dan Nilai Tradisional Provinsi Maluku dan Maluku Utara.

[15] Creswell, J. W. (2015). Penelitian Kualitatif \& Desain Riset Memilih Diantara Lima Pendekatan. Pustaka Pelajar.

[16] Semiawan, C. R. (2010). Metode Penelitian Kualitatif.

[17] Hauerwas, S. (1995). Virtue and Character.

[18] Ruhulessin, J. C. (2005). Etika Publik: Menggali Tradisi Pela di Maluku. Salatiga: Universitas Kristen Satya Wacana. 